\title{
Coagulation changes and the influence of the early perfusate in the course of orthotopic liver transplantation (OLT) when aprotinin is used intra-operatively
}

\author{
G. Himmelreich, B. Kierzek, P. Neuhaus, K.-J. Slamer, M. Jochum \\ and $\mathrm{H}$. Riess
}

(Received 6 August 1990; accepted in revised form 5 November 1990)

\begin{abstract}
The changes in relevant haemostatic parameters during the course of ten orthotopic liver transplantation were studied when aprotinin was given intra-operatively. Increases of tissue-type $(P=0.008)$ and urokinase-type $(P=0.009)$ plasminogen activators during the anhepatic phase could be correlated with hyperfibrinolysis. Thrombin - antithrombin III complexes (TAT) increased after revascularization of the liver graft $(P=0.003)$. Parallel studies in the perfusate showed that TAT concentrations were $350 \%$ and protease inhibitor activities (antithrombin III. protein C) only $52 \%$ of the systemic circulation before reperfusion, suggesting that thrombin activation together with protease inhibitor consumption occurs during graft liver reperfusion. The relatively smaller increases in profibrinolytic parameters and a lower blood loss when compared with other groups may be explained by aprotinin administration in our patients.
\end{abstract}

Key words: Orthotopic liver transplantation, aprotinin, hyperfibrinolysis, tissue-plasminogen activator, urokinase-type plasminogen activator, thrombin - antithrombin III complexes, disseminated intravascular coagulation, perfusate.

\section{Introduction}

Orthotopic liver transplantation (OLT) has become an established and accepted method in end-stage liver diseases. ${ }^{1.2}$ In spite of refined surgical techniques, bleeding remains a critical problem, influencing shortand long-term outcome. ${ }^{2}$

Obviously, the replacement of an insufficiently functional liver by a liver graft has a considerable impact on the coagulation and fibrinolytic systems. Pre-existing disturbances of haemostasis due to impaired synthesis of clotting factors and inhibitors, as well as reduced clearance of proteases and protease-inhibitor complexes by the recipient's liver, may become further aggravated intra-operatively.

During the late anhepatic and the early reperfusion phases of OLT, signs of hyperfibrinolysis may be of causative importance for intra- and post-operative bleeding. ${ }^{3-6}$ In addition, prothrombin becomes activated during OLT, peaking in the reperfusion phase. ${ }^{4.6}$ The role of the liver graft and its perfusate in the haemostatic balance after reperfusion have been discussed ${ }^{4.6}$ but not previously investigated.

Aprotinin, a parenterally administered proteinase inhibitor from bovine lung, ${ }^{7-9}$ inhibits kallikrein, an important activator of contact activation, triggering the intrinsic coagulation cascade as well as the intrinsic fibrinolytic system. ${ }^{10,11}$ In addition, aprotinin inhibits plasmin, trypsin and, to some extent, human urokinase. ${ }^{8}$ The toxicity of aprotinin is extremely low $^{8}$ and the tolerability of very high doses is good. . $^{712}$

In the present study, we investigated relevant parameters of the coagulation and fibrinolytic systems in samples taken in the course of ten consecutive OLTs

G. Himmelreich, B. Kierzek and H. Riess are with the Department of Internal Medicine, P. Neuhaus is with the Department of Surgery and K.J. Slamer is with the Institute of Anesthesiology. all at the Universitatsklinikum Rudolf Virchow. 1000 Berlin 19. Germany: M. Jochum is with she Department of Clinical Chemistry and Clinical Biochemistry. Chirurgische Klinik Innenstadt der Universität München. 8000 Mänchen 2, Germany. Address correspondence to Dr med. G. Himmelreicb. Gaubius Institute. Herenstraat Sd, Postbus 612, 2300 AP Leiden, Germany. 
when aprotinin was administered intra-operatively. In addition, we investigated for the first time the liver graft perfusate to establish its contribution to coagulation changes after reperfusion.

\section{Materials and methods}

A consecutive series of 10 patients with terminal liver disease (Table 1) underwent their first OLT at the University Hospital Rudolf Virchow, Charlottenburg, between 19 August 1989 and 23 November 1989. OLT was performed by standard techniques using a veno. venous bypass. ${ }^{13.14}$

The host liver was mobilized during the pre-anhepatic phase. The anhepatic phase begins with occlusion of the blood flow to the host liver and ends with the insertion of the liver graft in the patient's circulation. The reperfusion phase lasts until the end of surgery.

Packed red blood cells (RBC) and fresh-frozen plasma (FFP) were used to compensate for intra-operative blood loss. Before the anhepatic phase, at the end of the anhepatic phase and $1 \mathrm{~h}$ after reperfusion, $0.5 \times 10^{6}$ Kallikrein Inactivator Units (KIU) aprotinin (Trasylol, Bayer, Leverkusen, Germany) were given intravenously.

For cold storage of the graft liver Belzer UW-CSS solution (Du Pont, Paris, France) was used.

Blood samples were taken from the arterial line, after induction of anaesthesia (1), $5 \mathrm{~min}$ before (2) and $10 \mathrm{~min}$ after (3) the beginning of the anhepatic stage, $5 \mathrm{~min}$ before the reperfusion phase (4), and $5 \mathrm{~min}(5), 15 \mathrm{~min}$ (6), $60 \mathrm{~min}(7)$ and $12 \mathrm{~h} \mathrm{(8)} \mathrm{after} \mathrm{reperfusion.} \mathrm{In}$ addition, a sample of the perfusate released from the liver graft vein by flushing with arterial blood, was taken before opening the hepato-caval anastomosis (P). Blood samples were anticoagulated with a $1 / 10$ volume of trisodium citrate and, in addition, aliquots were acidified with acetic acid for the determination of tissue-type plasminogen activator (tPA) and urokinase-type plasmin-

Table 1. Diagnosis and characteristics of 10 patients undergoing orthotopic liver transplantations

\begin{tabular}{lccccc}
\hline Diagnosis & No. & Female & $\begin{array}{c}\text { Male } \\
\text { Mean age } \\
\text { (yrs) }\end{array}$ & $\begin{array}{c}\text { Age range } \\
\text { (yrs) }\end{array}$ \\
\hline $\begin{array}{c}\text { Postnecrotic } \\
\text { cirthosis }\end{array}$ & 4 & 1 & 3 & 51 & $45-64$ \\
$\begin{array}{c}\text { Alcoholic } \\
\text { cirrhosis }\end{array}$ & 4 & 3 & 1 & 48 & $39-55$ \\
$\begin{array}{c}\text { Budd-Chiari } \\
\text { syndrome }\end{array}$ & 1 & 1 & - & 46 & - \\
$\begin{array}{c}\text { Secondary biliary } \\
\text { cirthosis } \\
\text { (erythrohepatic } \\
\text { protoporphyrie) }\end{array}$ & 1 & - & 1 & 51 & - \\
\begin{tabular}{c} 
Total \\
\hline
\end{tabular} & 10 & 5 & 5 & 49 & $39-64$ \\
\hline
\end{tabular}

ogen activator (UPA) activities. Another blood sample was anticoagulated with a mixture of trisodium citrate, theophylline, adenosine and dipyridamole for the determination of plasminogen activator inhibitor activity (PAI). The specimens were gently mixed and centrifuged at $3000 \mathrm{rpm}$ for $20 \mathrm{~min}$ and the supernatant frozen at $-70^{\circ} \mathrm{C}$. Whole blood anticoagulated with trisodium citrate was used for thromboelastography (TEG).

The following parameters were measured using commercially available kits: D-dimer, fibrin monomer. free protein $\mathrm{S}$ antigen, protein $\mathrm{C}$ activity (Boehringer Mannheim, Mannheim, Germany), antithrombin III activity, plasminogen activity, alpha-2-antiplasmin activity, $C_{1}$-inhibitor activity (Behring Werke AG, Marburg, Germany) and fibrinogen according to Clauss (Hoffmann-La Roche, Basel, Switzerland).

tPA and PAI activities were determined by using a chromogenic substrate method and $\mathrm{PA}$ antigen was measured in a solid-phase enzyme immunoassay (Kabi, Stockholm, Sweden).

An immunosorbent activity assay for the combined determination of single-chain urokinase-type plasminogen activator (scuPA) and two-chain urokinase-type plasminogen activator (tcuPA) activities was used (Biopool, Umea, Sweden). UPA antigen was estimated by an enzyme immunoassay (Biopool). Plasmin-alpha-2. antiplasmin complexes (PAP) were determined by an enzyme immunoassay (Technoclone, Vienna, Austria). Thrombin - antithrombin III (TAT) complexes were determined by an enzyme immunoassay (Behring Werke AG, Marburg, Germany). Aprotinin was estimated by enzyme immunoassay according to Mueller-Esterl. ${ }^{15}$

TEG of recalcified whole blood was performed using a thromboelastograph (Hellige, Freiburg, Germany). Whole-blood clot lysis times (WBLTs) (the time between the maximal amplitude and complete lysis in the TEG) below $90 \mathrm{~min}$, or between 90 and $120 \mathrm{~min}$, were taken to indicate severe or mild hyperfibrinolysis, respectively.

\section{Statistical analysis}

The significance of differences within groups were tested using the Wilcoxon rank-sum test. Values for $P<0.05$ were considered to be significant.

\section{Results}

The blood used during the operation and one to three days after OLT is shown in Table 2.

In TEG, signs of increasing fibrinolytic activation became apparent during the course of each OLT. Two patients had signs of mild and three patients signs of severe hyperfibrinolysis (see above) in at least one blood sample. Signs of hyperfibrinolysis occurred first at the end of the anhepatic phase in three and in the early 
Table 2. Blood use in 10 patients undergoing orthotopic liver transplantations

\begin{tabular}{lcc}
\hline & Median & Range \\
\hline $\begin{array}{l}\text { During transplantation } \\
\text { RBC (units) }\end{array}$ & 6.5 & $4-26$ \\
FFP (units) & 7 & $1-39$ \\
1 day after transplantation & 1.5 & $0-8$ \\
RBC (units) & 4 & $0-15$ \\
FFP (units) & & \\
$1-3$ days after transplantation & 1.5 & $0-8$ \\
RBC (units) & 8 & $0-16$ \\
FFP (units) & & \\
\hline
\end{tabular}

reperfusion phase in two of the five patients with clearly accelerated fibrinolysis.

Levels of tPA activity and antigen increased during the pre-anhepatic and anhepatic phases with maxima at the end of the anhepatic phase. The decline observed immediately after reperfusion became significant after $60 \mathrm{~min}$ for the tPA activity $[P(4 / 5)=0.006]$ and after $15 \mathrm{~min}$ for the tPA antigen $[P(4 / 5)=0.003]$ (Figure 1).

Plasma levels of PAI activity did not change significantly during the pre-anhepatic and anhepatic phases. Sixty minutes and $12 \mathrm{~h}$ after reperfusion there were significant elevations in comparison with the preoperative levels (Figure 1).

UPA activity showed a significant increase in the anhepatic phase with a maximum at the end of the anhepatic phase (Figure 2). UPA antigen increased significantly after reperfusion whereas the $\mathrm{C}_{1}$-inhibitor decreased significantly at the same time $[P(4 / 5)=$ 0.004] (Figure 2).

PAP levels $(n=3)$ increased in parallel with tPA and uPA activities during the anhepatic phase and decreased in the reperfusion phase (Figure 3).

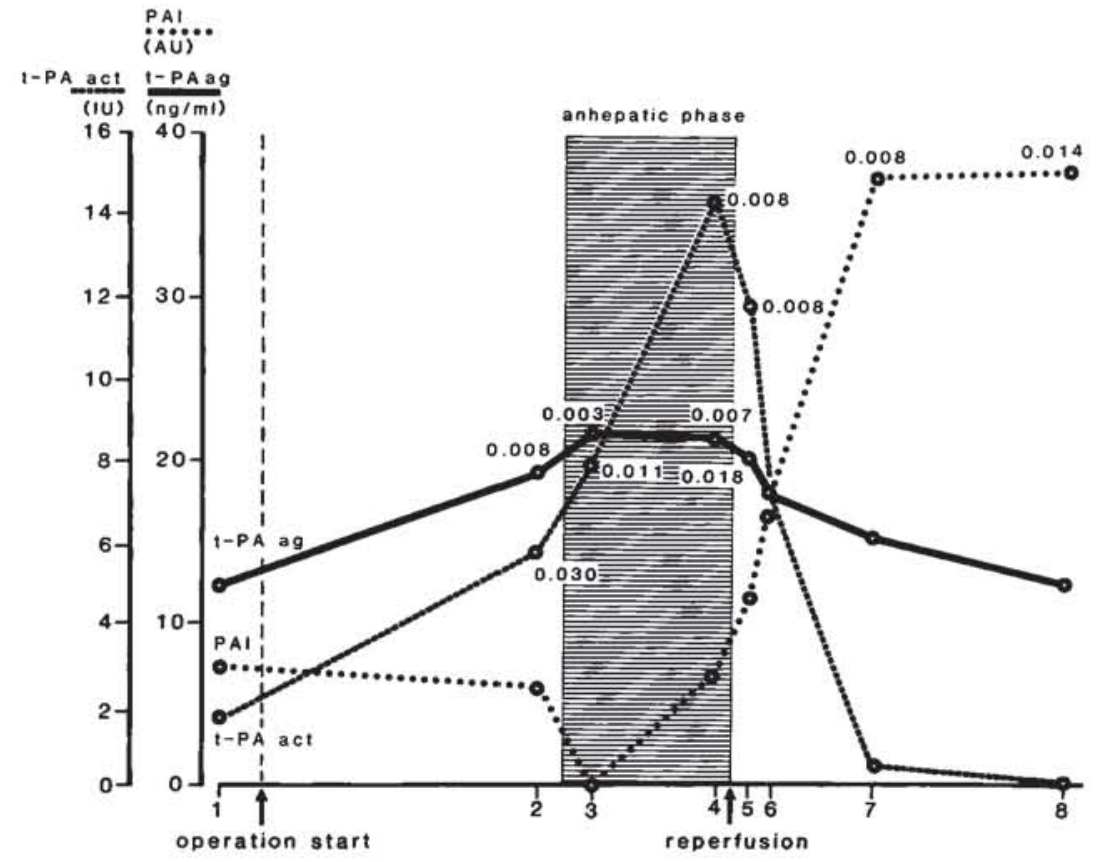

Figure 1. Median values of $\mathrm{PA}$ antigen (tPA ag), $\mathrm{tPA}$ activity (tPA act) and PAI activity (PAI) in 10 orthotopic liver transplantations. Significant $P$ values $(1 / x)$ are shown. For reference values see Table 3

Statistical evaluation

$\mathrm{tPA}$ activity/tPA antigen/PAI

\begin{tabular}{lrrrrrrrr}
\hline$x$ & \multicolumn{1}{c}{$\mathrm{1}$} & \multicolumn{1}{c}{2} & \multicolumn{1}{c}{3} & \multicolumn{1}{c}{4} & \multicolumn{1}{c}{5} & \multicolumn{1}{c}{6} & \multicolumn{1}{c}{7} & \multicolumn{1}{c}{8} \\
\hline Range & $0-7.8$ & $0-22.8$ & $8-27.4$ & $0-30.4$ & $8-142$ & $7-32.6$ & $0-22.8$ & $0-9.0$ \\
Range & $6.2-23.8$ & $10.4-52.3$ & $15.8-72.5$ & $14.3-44.9$ & $12.4-38.5$ & $9.0-30.0$ & $6.6-20.6$ & $8.3-19.9$ \\
Range & $0.3-35.8$ & $0-34.5$ & $0-32.2$ & $0-34.8$ & $0-26.2$ & $0-37.8$ & $6.6-40$ & $0-40$ \\
\hline
\end{tabular}




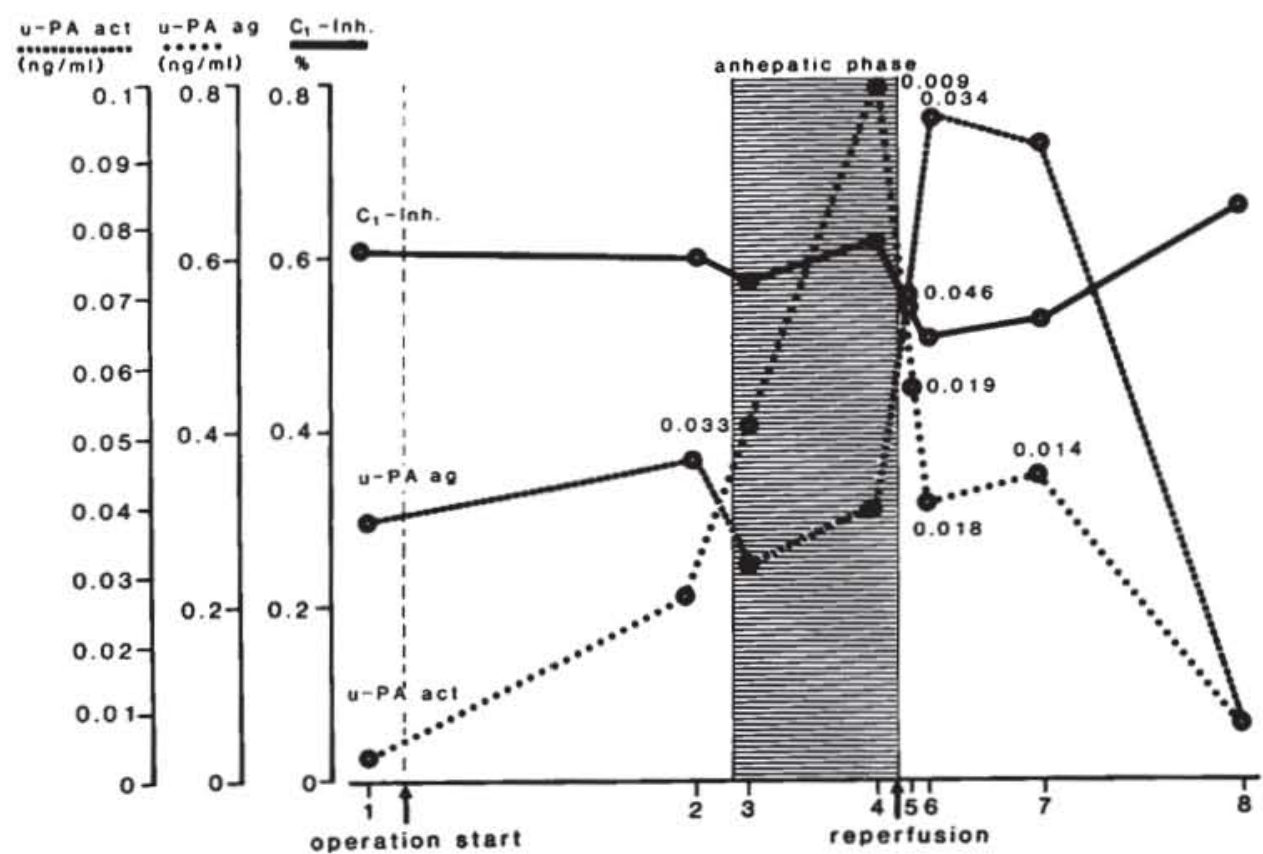

Figure 2. Median values of uPA antigen (uPA ag), uPA activity (uPA act) and $\mathrm{C}_{1}$-inhibitor $\left(\mathrm{C}_{1}\right.$-inh) in 10 orthotopic livet transplantations Significant $P$ values $(1 / x)$ are shown. For reference values see Table 3.

Statistical evaluations

uPA activity/uPA antigen/ $C_{1}$-inhibitor

\begin{tabular}{lcccccccc}
\hline $\boldsymbol{x}$ & 1 & 2 & 3 & 4 & 5 & 6 & 7 & 8 \\
\hline Range & $0-0.08$ & $0-0.3$ & $0-0.15$ & $0-0.52$ & $0-0.27$ & $0.10-0.3$ & $0-0.15$ & $0-0.12$ \\
Range & $0-1.6$ & $0-3.25$ & $0-6.25$ & $0-3.95$ & $0-5.8$ & $0-6.1$ & $0-6.5$ & $0-3$ \\
Range & $15-135$ & $58-117$ & $48-110$ & $55-107$ & $45-99$ & $48-96$ & $55-114$ & $64-92$ \\
\hline
\end{tabular}

D-dimers were significantly higher at the end of the anhepatic phase than in the pre-anhepatic phase (Figure 4).

TAT complexes and fibrin monomers increased significantly immediately after reperfusion (Figure 4), whereas AT III activity and free protein $\mathrm{S}$ antigen demonstrated a significant fall after reperfusion (Figure s).

According to the intermittent bolus administration of aprotinin, peak levels were seen before the anhepatic stage, at the end of the anhepatic phase and $60 \mathrm{~min}$ after reperfusion (Figure 6).

TAT complexes and uPA activity in the perfusate were significantly elevated as compared with plasma samples of the systemic circulation taken immediately before reperfusion, whereas $\mathrm{PA}$ antigen, fibrinogen and, most pronounced, the activities of the protease inhibitors $\mathrm{C}_{1}$-inhibitor. AT III and protein C were significantly decreased. UPA antigen, D-dimers, fibrin monomers, free protein $S$ antigen and the activities of $t P A, P A I$ and plasminogen in the perfusate were comparable to the corresponding levels in the systemic circulation (Table 3 ).

\section{Discussion}

The relevance of haemostatic parameters measured during OLT depends on the type, amount and timing of replacement therapy intra-operatively. There were no concentrates of clotting factors or inhibitors given to our patients during OLT and the amount of RBC and FFP transfused is clearly below those reported from other centres (Table 2) ${ }^{3.6 .16 .17}$ Operation time, cold ischaemic time of the graft liver and the duration of the anhepatic phase (Table 4) are other variables that have to be considered. 


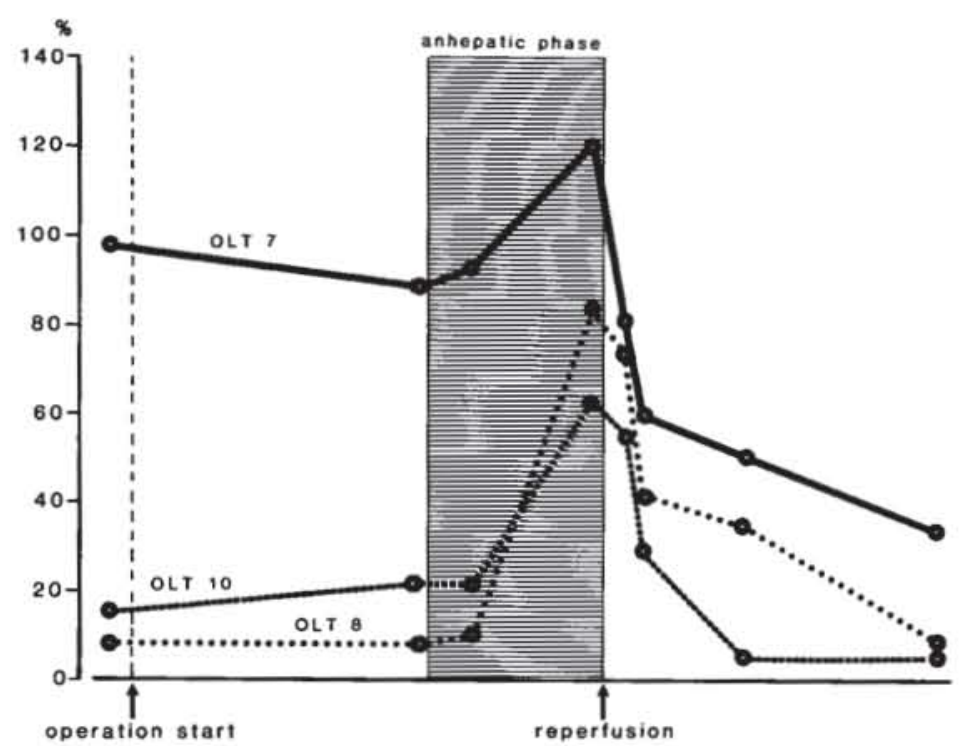

Figure 3. Plasmin - antiplasmin (PAP) complexes in three orthotopic liver transplantations. Reference values: $<1.0$

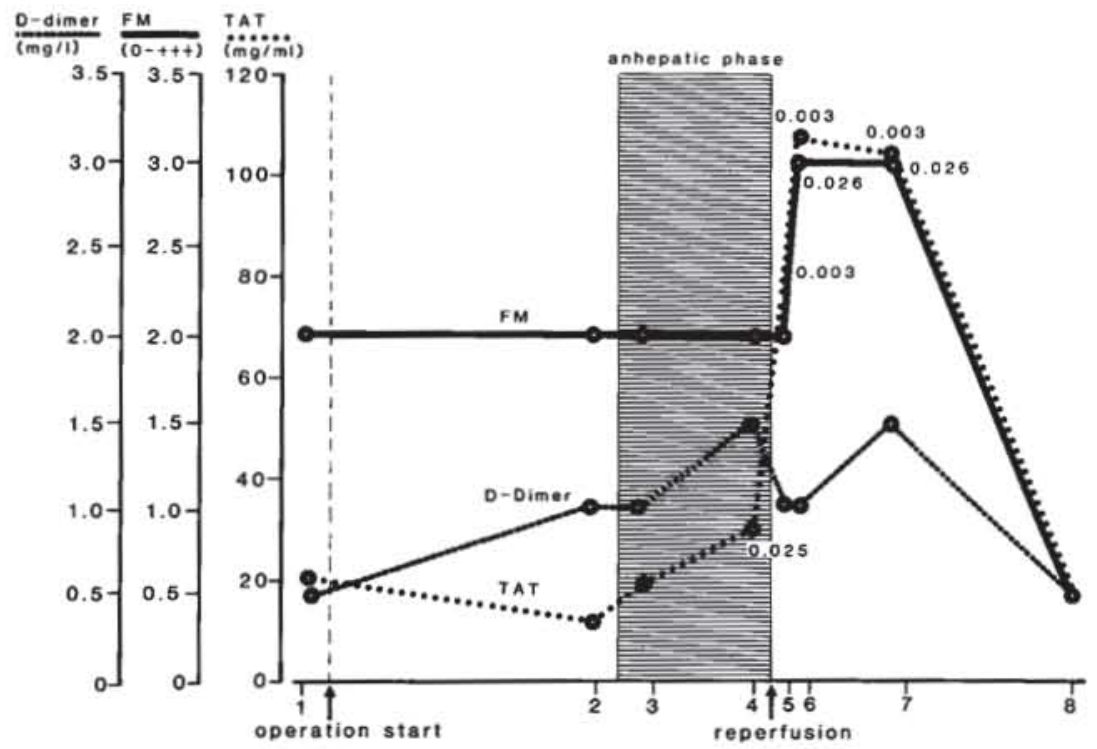

Figure 4. Median values of thrombin - antithrombin III (TAT) complexes, D-dimers and fibrin monomers (FM) in 10 orthoropic liver transplan. tations. Significant $P$ values $(1 / x)$ are shown. For reference values see Table 3.

Statistical evaluations

TAT/fibrin monomer/D-dimet

\begin{tabular}{lcccccccc}
\hline$x$ & 1 & 2 & 3 & 4 & 5 & 6 & 7 & 8 \\
\hline Range & $5.1-39.0$ & $2.8-57$ & $11.2-58.5$ & $15.7-270$ & $26-216$ & $34-195$ & $35.8-192$ & $7.8-48.5$ \\
Range & $0-3$ & $0-3$ & $0-3$ & $0-3$ & $1-3$ & $1-3$ & $1-3$ & $0-2$ \\
Range & $0-16$ & $0-2$ & $0-2$ & $0-4$ & $0-8$ & $0-4$ & $0-8$ & $0-2$ \\
\hline
\end{tabular}


Because of the beneficial effect of aprotinin on the haemorrhagic diathesis observed in the course of OLT in former patients, ${ }^{18}$ aprotinin was given prophylactically as boli with $0.5 \times 10^{6} \mathrm{KIU}$ three times during OLT. Neither prothrombotic side effects nor impairment of renal and hepatic functions were observed in a study using very high aptotinin dosage $\left(17.5 \times 10^{6} \mathrm{KIU} /\right.$ $24 \mathrm{~h}$ ) in patients with polytrauma ${ }^{7}$ or in patients undergoing cardiac surgery $\left(5 \times 10^{6} \mathrm{KIU} / 2 \mathrm{~h}\right) .{ }^{19.20}$

There are at least two main aspects to be distinguished in the evaluation of haemostatic changes during OLT. (1) In the anhepatic phase, reduced hepatic clearance of enzymes and inhibitors, surgical stress, vascular manipulations and the venovenous bypass may further derange pre-existing disturbances of haemostasis. (2) Despite extensive flushing of the graft liver in our patients, conservation fluid together with mediators released from the graft enter the systemic circulation during reperfusion.

Our results demonstrated a steady increase of tPA activity and antigen levels peaking immediately before the reperfusion phase. Using the same assays we found maximal values clearly lower than those reported by Porte et al. ${ }^{6}$ We also observed a concomitant increase of uPA activity - a result which has not been described before. Thus, in addition to the intrinsic pathway, the intrinsic fibrinolytic system may be involved in the development of hyperfibrinolysis observed in TEG. The PAP and D-dimer levels took a parallel course to the plasminogen activators demonstrating the in vivo creation and effect of plasmin.

Immediately after reperfusion, an increase of TAT

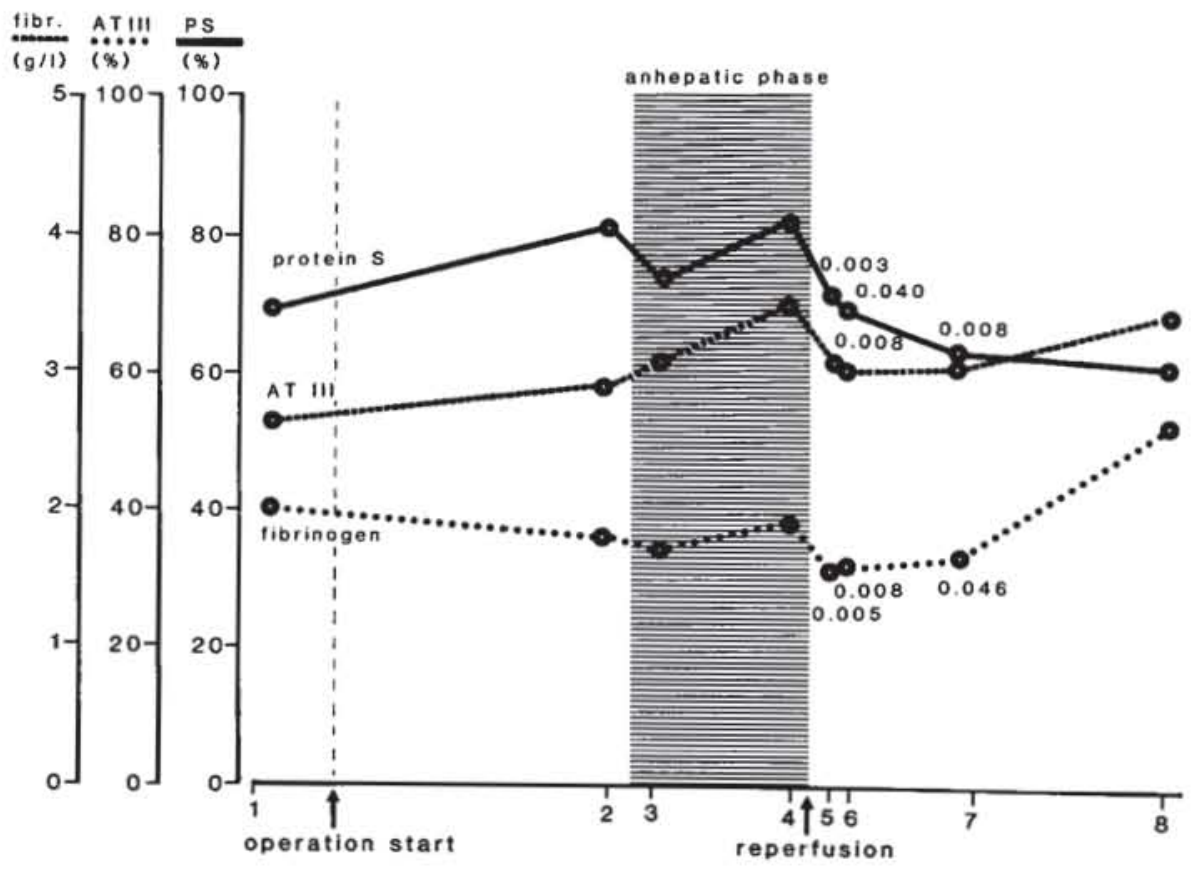

Figure 5. Median values of fibrinogen, free protein $\mathrm{S}$ antigen (protein S), antithrombin III (AT III) in 10 orthotopic liver transplantations. Significant $P$ values $(4 / x)$ are shown. For reference values see Table 3 .

Statistical evaluation:

Protein C/free protein S antigen/AT III/von Willebrand antigen/fibrinogen

\begin{tabular}{lcccccccc}
\hline $\boldsymbol{x}$ & 1 & 2 & 3 & 4 & 5 & 6 & 7 & 8 \\
\hline Range & $7-69$ & $7-60$ & $7-50$ & $9-54$ & $12-39$ & $18-42$ & $17-38$ & $27-83$ \\
Range & $44-104$ & $46-118$ & $35-118$ & $41-98$ & $38-85$ & $35-98$ & $41-92$ & $43-78$ \\
Range & $33-80$ & $31-87$ & $40-72$ & $35-89$ & $31-79$ & $42-76$ & $51-75$ & $39-79$ \\
Range & $223-453$ & $270-397$ & $257-541$ & $194-405$ & $213-335$ & $187-303$ & $220-358$ & $194-365$ \\
Range & $0.2-3.4$ & $1.4-3.0$ & $1.2-2.7$ & $1.1-2.7$ & $0.6-2.3$ & $1.1-2.1$ & $1.1-2.5$ & $1.6-3.1$ \\
\hline
\end{tabular}


complexes has been reported 4.6 and we have confirmed these results. In addition, elevated fibrin monomers and decreases in AT III activity, free protein $\mathrm{S}$ antigen and fibrinogen levels after reperfusion suggest that a consumption of haemostatic factors including prothrombin activation takes place.

The elevations of the acute phase proteins $\mathrm{PAI}$ and fibrinogen in the course of the reperfusion phase may also be explained by graft liver synthesis.

The graft liver perfusate is a mixture of instreaming arterial blood and conservation fluid, which explains the fact that most of the haemostatic parameters measured in the perfusate are comparable to or lower than those determined in blood samples of the systemic circulation immediately before teperfusion (Table 3). In contrast, TAT complexes were elevated in the perfusate, indicating an increased thrombin formation in the liver graft whereas the activities of the protease inhibitors protein C. AT III and $C_{1}$-inhibitor were overproportionally lowered, suggesting their consumption during graft liver perfusion. This could explain the signs of disseminated intravascular coagulation (DIC) occurring after reperfusion.

Furthermore, high uPA activity in contrast to low tPA activity and antigen concentration could be measured in the perfusate. UPA antigen levels showed a trend towards higher levels in the perfusate than in the systemic circulation. This was followed by an increase of the uPA antigen in the systemic circulation after reperfusion. The fact that uPA activity does not increase after reperfusion despite peaking UPA antigen may be explained by complex inactivation of uPA by PAI as well as by tPA-dependent and plasmin-mediated scuPA activation.

Our results concerning changes of the coagulation and fibrinolytic systems in patients undergoing OLT confirm previous reports ${ }^{3-6}$ and seem to advance them, in that we have shown that hyperfibrinolysis developing mainly in the anhepatic phase of OLT precedes the appearance of DIC, which in turn may be triggered by mediators from the graft liver entering the systemic circulation.

Therapeutic suggestions derived from these data may include the supplementation with AT III shortly before reperfusion to antagonize the increased prothrombin activation after reperfusion. Furthermore, a prolonged flushing of the liver in order to achieve a reduction of the entrance of active mediators from the graft liver in the recipient's circulation is preferable.

The relatively small blood use observed, compared with other groups, ${ }^{3.3 .6}$ may in part be explained by the administration of aprotinin to our patients as well as by the short operation time. However, our results do not clarify the role of aprotinin in our patients since a control

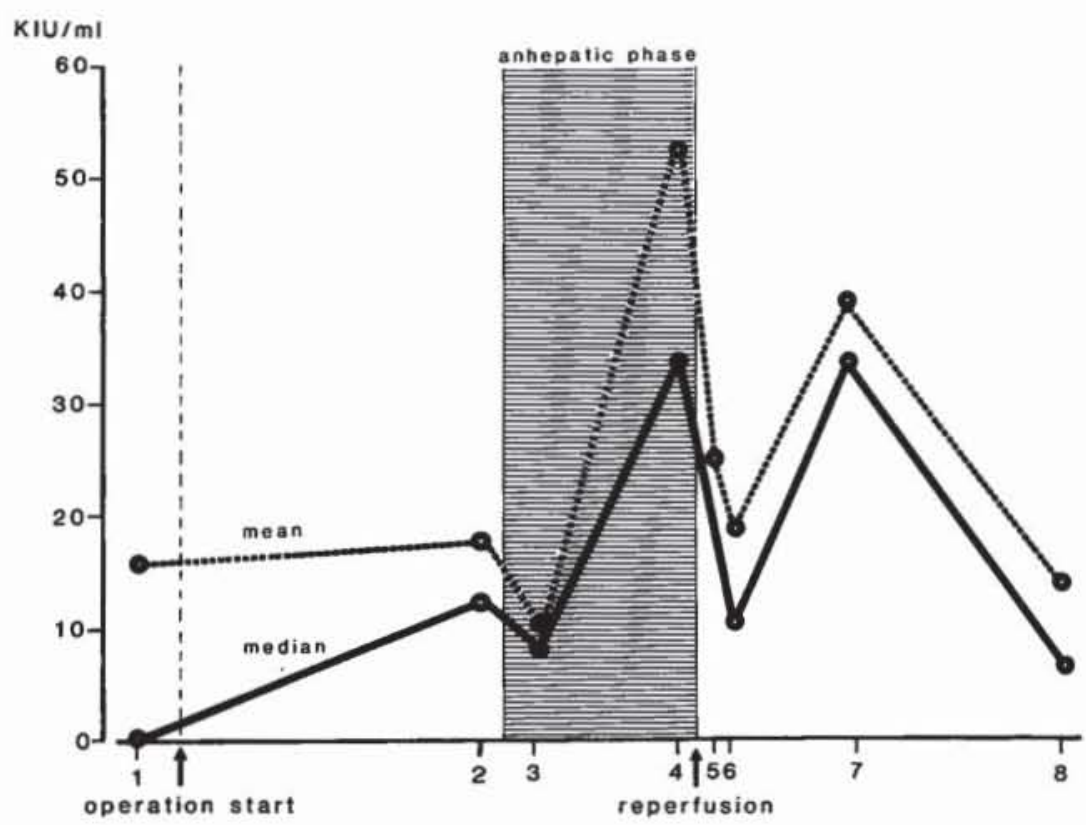

Figure 6. Median and mean aprotinin concentrations in 10 orthotopic liver transplantations. Aprotinin was given before the anhepatic phase. at the end of the anhepatic phase and $60 \mathrm{~min}$ after reperfusion. 
Table 3. Comparison of haemostatic parameters in the perfusate (P) of the graft liver with the systemic circulation $5 \mathrm{~min}$ before reperfusion (4)

\begin{tabular}{|c|c|c|c|c|c|}
\hline Parameters & Reference & $t$ & Median & Range & $P(4 / P)$ \\
\hline \multirow{2}{*}{$\begin{array}{l}\text { tPA act } \\
\text { (IU) }\end{array}$} & \multirow[t]{2}{*}{$0.3-2.0$} & 4 & 14.7 & $0-30.4$ & \multirow[t]{2}{*}{0.070} \\
\hline & & $P$ & 10.9 & $0-15.6$ & \\
\hline \multirow{2}{*}{$\begin{array}{l}\mathrm{PA} \text { ag } \\
\quad(\mathrm{ng} / \mathrm{ml})\end{array}$} & \multirow[t]{2}{*}{$1.2-12.5$} & 4 & 21.4 & $14.3-44.9$ & \multirow[t]{2}{*}{0.014} \\
\hline & & $\mathrm{P}$ & 17.9 & $7.2-28.8$ & \\
\hline \multirow{2}{*}{$\begin{array}{l}\text { uPA act } \\
(\mathrm{ng} / \mathrm{ml})\end{array}$} & preliminary & 4 & 0.10 & $0-0.52$ & \multirow[t]{2}{*}{0.050} \\
\hline & range $<0.1$ & $P$ & 0.16 & $0-0.31$ & \\
\hline \multirow{2}{*}{$\begin{array}{l}\text { uPA ag } \\
\quad(\mathrm{ng} / \mathrm{ml})\end{array}$} & preliminary & 4 & 0.3 & $0-3.95$ & \multirow[t]{2}{*}{0.200} \\
\hline & range $<0.7$ & $P$ & 0.32 & $0-6.00$ & \\
\hline \multirow{2}{*}{$\begin{array}{l}\mathrm{C}_{1} \text {-inhibitor } \\
(\%)\end{array}$} & $75-130$ & 4 & 77.0 & $55-107$ & \multirow[t]{2}{*}{0.006} \\
\hline & & $\mathrm{P}$ & 66.0 & $27-92$ & \\
\hline \multirow{2}{*}{$\begin{array}{r}\text { PAl act } \\
(A U)\end{array}$} & $0-39$ & 4 & 84.0 & $0-34.8$ & \multirow[t]{2}{*}{0.107} \\
\hline & & $\mathrm{P}$ & 68.0 & $0-27.5$ & \\
\hline \multirow{2}{*}{$\begin{array}{l}\text { plasminogen } \\
\text { (\%) }\end{array}$} & $65-150$ & 4 & 49.0 & $22-74$ & \multirow[t]{2}{*}{0.380} \\
\hline & & P & 43.0 & $10-77$ & \\
\hline \multirow{2}{*}{$\begin{array}{c}\text { fibrinogen } \\
(\mathrm{g} / \mathrm{l})\end{array}$} & $1.6-4.0$ & 4 & 1.92 & $1.1-2.7$ & \multirow[t]{2}{*}{0.018} \\
\hline & & $\mathrm{P}$ & 1.54 & $0.5-2.2$ & \\
\hline \multirow{2}{*}{$\begin{array}{r}\text { AT III } \\
(\%)\end{array}$} & $75-130$ & 4 & 70 & $35-89$ & \multirow[t]{2}{*}{0.004} \\
\hline & & $\mathrm{P}$ & 38 & $26-56$ & \\
\hline \multirow{2}{*}{$\begin{array}{c}\text { protein C } \\
(\%)\end{array}$} & $70-140$ & 4 & 24.0 & $8-54$ & \multirow[t]{2}{*}{0.003} \\
\hline & & $\mathrm{p}$ & 12.0 & $0-24$ & \\
\hline \multirow{2}{*}{$\begin{array}{l}\text { f. prot. S ag } \\
(\%)\end{array}$} & $6 s-150$ & 4 & 82.5 & $41-98$ & \multirow[t]{2}{*}{0.069} \\
\hline & & $\mathrm{P}$ & 70.0 & $11-106$ & \\
\hline \multirow{2}{*}{$\begin{array}{c}\text { fibrin monomer } \\
(0-+++)\end{array}$} & 0 & 4 & 2 & $0-3$ & \multirow[t]{2}{*}{0.380} \\
\hline & & $\mathrm{P}$ & 2 & $0-3$ & \\
\hline \multirow{2}{*}{$\begin{array}{l}\text { D-dimet } \\
(\mathrm{mg} / \mathrm{l})\end{array}$} & $<0.5$ & 4 & 1.5 & $0-4$ & \multirow[t]{2}{*}{0.199} \\
\hline & & P & 2.0 & $0-16$ & \\
\hline \multirow{2}{*}{$\begin{array}{l}\text { TAT complexes } \\
(\mathrm{mg} / \mathrm{ml})\end{array}$} & $1.0-4.1$ & 4 & 30 & $15-270$ & \multirow[t]{2}{*}{0.005} \\
\hline & & $\mathrm{P}$ & 105 & $10-324$ & \\
\hline
\end{tabular}

Table 4. Parameters of ten orthotopic livet transplantations

\begin{tabular}{lcc}
\hline & Median & Range \\
\hline Cold ischaemic time (min) & 575.5 & $330-744$ \\
Duration of the operation (h) & 6.5 & $5-8$ \\
Duration of the anhepatic phase (min) & 83.5 & $73-106$ \\
Time of hospital stay (days) & 25 & $19-159$ \\
\hline
\end{tabular}

group without aprotinin was not studied. In addition, the concentration of aprotinin in the plasma did not achieve a level suggested to be of therapeutic significance by other investigators. ${ }^{7.8}$

\section{References}

1. Maddrey WC, Van Thiel DH. Liver transplantation: an overview. Hepatology 1988; 8: 259-948.

2. Starzl TE, Demetris AJ, van Thiel D. Liver transplantation. $N$ EnglJ Med 1984; 311: 1658 - 1664.

3. Dzik W, Arkin CF, Jenkins RL, et al. Fibrinolysis during liver transplantation in humans: role of tissue-type plasminogen activator. Blood 1988; 71: 1090-1095.

4. Harper PL. Luddington RJ. Jennings I, et al. Coagulation changes following hepatic tevascularisation during live transplantation. Transplantation 1989; 48: 603-607.

5. Palareti G. De Rosa V. Fortunato G, et al. Control of hemostasis during orthotopic liver transplantation. Fibrinolysis 1988; 2 (suppl. 3): $61-66$

6. Porte RJ, Bontempo FA, Knot EAR, et al. Systemic effects of tissue plasminogen activator associated fibrinolysis and its relation to thrombin generation in orthotopic liver transplantation. Transplantation 1989: 47: $978-984$.

7. Clasen C. Jochum M, Mueller-Esterl W. Feasibility study of very high aprotinin dosage in polytrauma patients. In: Schlag G, Redl H eds. First Vienna Shock Forum, Part A: Pathophysiological role of mediators and mediator inbibitors in shock. New York: Alan R. Liss, 1987: 175 - 183.

8. Fritz H, Wunderer G, Jochum M. Biochemistry and applications of aprotinin, the kallikrein inhibitor from bovine organs. Arzneim-Forsch/Drug Res 1983; 33: $479-494$

9. Verstraete M. Clinical applications of inhibitors of fibrinolysis. Drugs 1985; 29: $236-261$

10. Bachmann F. Fibrinolysis. In: Verstraete M. Vermylen J. Lijenen HR, et al. eds. Thrombosis and hemostasis. Leuven: Leuven University Press, 1987: 227-265.

11. Kok P, Nilsson T. Assay characteristics and fibrin affinity of plasminogen activators of the intrinsic fibrinolytic system. Thromb Res 1986; 41: $197-209$

12. Haberland GL, Matis P. Trasylol cin Proteinaseninhibitor bei chirurgischen und internen Indikationen. Med Welt 1967: 18: 1367 - 1376

13. Neuhaus P, Bechstein WO, Hopf U, et al. Indikationen und aktuelle Entwicklung der Lebertransplantation. Leber Magen Darm 1989; 19: $289-308$.

14. Neuhaus P, Blumhardt G, Bechstein WO, et al. Side-toside anastomosis of the common bile duct is the method of choice for biliary tract reconstruction after livet transplan tation. Transplant Proc (in press)

15. Müller-Esterl W, Oettl A. Truscheit E, et al. Monitoring of aprotinin plasma levels by an enzyme-linked immunosorbent assay (ELISA). Fresenius Z Anal Cbem 1984; 317: 718.

16. Owen CA, Rettke SR, Bowic EJW, et al. Hemostatic evaluations of patients undergoing liver transplantation. Mayo Clin Proc 1987; 62: 761 - 772.

17. Ritter DM, Owen CA, Bowie EJW, et al. Evaluation of preoperative hematology-coagulation screening in liver transplantation. Mayo Clin Proc 1989; 64: 216-233.

18. Neuhaus P. Bechstein WO, Lefebre B, et al. Effect of aprotinin on intraoperative bleeding and fibrinolysis in liver transplantation (letter). Lancet 1989; ii: 924-925.

19. Bidstrup BP, Royston D, Sapsford RN, et al. Reduction in blood use after cardiopulmonary bypass with high dose aprotinin (Trasylol). J Thorac Cardiovasc Surg 1986; 91: $436-442$.

20. Dietrich W, Barankay A, Dilthey G, et al. Reduction of homologous blood requirement in cardiac surgery by intraoperative aprotinin application-clinical experience in 152 cardiac surgical patients. J Thorac Cardiovasc Surg 1989; $37: 92-98$. 